\title{
EXCHANGE
}

\section{An Economic Analysis of Sex Discrimination Laws}

\author{
Richard A. Posner †
}

There is now a substantial economic literature on discrimination. The literature focuses on racial discrimination but has implications for other forms of discrimination as well, including sex discrimination. There is also a substantial economic literature on the extent and causes of disparities between men and women in wages, employment level, and other measures of professional attainment. ${ }^{2}$ At the intersection of the two literatures one finds a number of studies of the economics of sex discrimination in employment. ${ }^{3}$ There is also-it goes without saying-an enormous legal literature on sex discrimination law, again focused on employment. But there is relatively little writing on sex discrimination law from an eco-

$\dagger$ Judge, United States Court of Appeals for the Seventh Circuit; Senior Lecturer, The University of Chicago Law School. The comments of Mary Becker, Dennis Black, John Donohue, Lewis Kaplow, Cass Sunstein, and participants in the law and economics workshop at Harvard Law School, and the research assistance of Seung C. Kim, are gratefully acknowledged.

I See my book, Richard A. Posner, Economic Analysis of Law ch 27 (Little, Brown, 3d ed 1986), for an introduction to the economics of discrimination with references to some of the leading studies.

${ }^{2}$ See, for example, Gary S. Becker, Human Capital, Effort, and the Sexual Division of Labor, 3 J Labor Econ S33 (1985); Victor R. Fuchs, Women's Quest for Economic Equality (Harvard, 1988); Morley Gunderson, Male-Female Wage Differentials and Policy Responses, $27 \mathrm{~J}$ Econ Lit 46 (1989) (a thorough review of the literature); and a particularly accessible, as well as up-to-date, introduction to the literature, Symposium: Women in the Labor Market, 3 J Econ Perspectives 3 (1989).

${ }^{3}$ For a recent review of this literature, see Janice Fanning Madden, The Persistence of Pay Differentials: The Economics of Sex Discrimination, in Laurie Larwood, Ann $\mathrm{H}$. Stromberg, and Barbara A. Gutek, eds, 1 Women and Work: An Annual Review 76 (Sage, 1985); and for an illustrative study see William T. Bielby and James N. Baron, Sex Segregation Within Occupations, 76 Am Econ Rev Papers \& Proc 43 (May 1986). 
nomic standpoint. ${ }^{4} \mathrm{My}$ objective in this paper is to examine the economic properties of the laws and doctrines relating to sex discrimination in employment. Although I am unable on the basis of existing information and analysis to estimate either the efficiency or the distributive effects of these laws and doctrines, I believe it is a plausible hypothesis-no stronger statement is possible-that sex discrimination law has not increased, and it may even have reduced, the aggregate welfare of women. Underlying this conclusion are four general arguments supported by smatterings of empirical evidence: (1) the sheer variety of practices that cluster together under the law's label "sex discrimination"; (2) the distributive complexities arising from interdependent positive utilities and joint consumption between men and women; (3) the pervasive conflicts of interest between different groups of women (for example, nonworking housewives and unmarried working women); and (4) the probably substantial, and growing, costs of administering sex discrimination laws. Arguments (2) and (3) are related ${ }^{5}$ and together help explain why women, despite being a majority of voters, may not have succeeded in obtaining effective antidiscrimination legislation.

- What there is focuses mainly but not exclusively on (1) comparable worth, (2) eliminating sex distinctions in longevity tables used for computing annuities and life insurance premiums, and (3) the use of econometric evidence in sex discrimination litigation. The following list, although by no means complete, is an extensive sample of the literature: Arthur P. Dempster, Employment Discrimination and Statistical Science, 3 Stat Sci 149 (1988) (and comments following by other scholars); Robert L. Moore, Are Male/Female Earnings Differentials Related to Life-Expectancy-Caused Pension Cost Differences?, 25 Econ Inquiry 389 (1987); Samuel A. Rea, Jr., The Market Response to the Elimination of Sex-Based Annuities, 54 S Econ J 55 (1987); Daniel R. Fischel and Edward P. Lazear, Comparable Worth and Discrimination in Labor Markets, 53 U Chi L Rev 891 (1986); George E. Johnson and Gary R. Solon, The Attainment of Pay Equity Between the Sexes by Legal Means: An Economic Analysis, 20 U Mich J L Ref 183 (1986); Jonathan S. Leonard, The Impact of Affirmative Action on Employment, $2 \mathrm{~J}$ Labor Econ 439 (1984); Andrea $\mathrm{H}$. Beller, Occupational Segregation by Sex: Determinants and Changes, $17 \mathrm{~J}$ Human Resources 371 (1982); George J. Benston, The Economics of Gender Discrimination in Employee Fringe Benefits: Manhart Revisited, 49 U Chi L Rev 489 (1982); Cotton M. Lindsay and Charles A. Shanor, County of Washington v. Gunther: Economic and Legal Considerations for Resolving Sex-Based Wage Discrimination Cases, 1 S Ct Econ Rev 185 (1982); Janet C. Hunt and Paul H. Rubin, The Economics of the Women's Movement, 35 Pub Choice 287 (1980); Butler D. Shaffer, Some Economic Considerations in Sex Discrimination Cases, 26 Labor L J 290 (1975); and Gunderson, $27 \mathrm{~J}$ Econ Lit at 53-68 (cited in note 2), and studies cited therein.

5 This is noted briefly in Hunt and Rubin, 35 Pub Choice at 292-94 (cited in note 4), who find that sex discrimination legislation is more likely to be enacted the lower the marriage rate, since single women tend to gain more from such legislation than married ones. 


\section{The Legal Background ${ }^{6}$}

A complex set of laws regulates sex discrimination in employment; its complexity may be an important reason why more economists have not studied sex discrimination law, as distinct from the phenomenon of sex discrimination. I begin with the federal statutes and judicial interpretation of them. The Equal Pay Act of $1963^{7}$ requires employers to pay their employees the same wages for "equal work" regardless of sex. Equal work is narrowly defined, and unequal pay for equal work is permitted if the employer can show that the inequality is due to something other than the sex of the employees. Title VII of the Civil Rights Act of $1964^{8}$ forbids sex discrimination in employment-in hiring, firing, promotion, and working conditions. Discrimination in pay is also included, so Title VII overlaps with the Equal Pay Act. "Discrimination" as used in Title VII essentially means disadvantage, but the employer can defend against a charge of sex discrimination by showing that the discrimination is necessary to its business. This is the "BFOQ" (bona fide occupational qualification) defense. ${ }^{9}$ A standard example is refusing to consider male actors for female acting parts. Finally, Executive Order No 11246, as amended in $1967,{ }^{10}$ forbids discrimination on the basis of sex by federal contractors, under pain of loss of their contracts.

Title VII was amended in 1972 to extend its coverage to public employers and small private employers and to enlarge the powers of the Equal Employment Opportunity Commission (EEOC). In the Pregnancy Discrimination Act of $1978,{ }^{11}$ Congress, repudiating the Supreme Court's decision in General Electric Co. $v$ Gilbert, ${ }^{12}$ further amended Title VII to forbid discrimination based on pregnancy, with the result that an employer's refusal to classify pregnancy as a disability or to include the medical costs of pregnancy in a health benefits plan for employees is now unlawful discrimination. And the courts have interpreted Title VII discrimination to

- See generally Charles A. Sullivan, Michael J. Zimmer and Richard F. Richards, $1 \mathrm{Em}$ ployment Discrimination ch 8 (Little, Brown, 2d ed 1988); see also index references to "sex discrimination" in volume 3 of this up-to-date, comprehensive, but one-sided treatise.

729 USC $\S 206$ (d) (1982).

- 42 USC $\$ 2000$ e (1982).

- 42 USC $\$ 2000 \mathrm{e}-2(\mathrm{e})$ (1982).

10 Executive Order 11246, 3 CFR 1964-65 Comp 339 (1965), as amended 3 CFR 1966-70 Comp 684 (1967).

${ }^{11} 42$ USC $\$ 2000 \mathrm{e}(\mathrm{k})$ (1982).

12429 US 125 (1976). 
include sexual harassment. ${ }^{13}$ Although Title VII has been held not to require employers to adopt "comparable worth,"14 several states have required it of their public employers. ${ }^{16}$ California has in addition required its private as well as its public employers to give female workers maternity leave; recently the Supreme Court held that such a requirement does not violate the Pregnancy Discrimination Act. ${ }^{16}$

The Equal Protection and Due Process Clauses have been held to forbid various forms of governmental sex discrimination, both state and federal. For example, the Equal Protection Clause has been interpreted to require the "degendering" of pension plans for public employees and to forbid differentiating spousal pension and fringe benefits on the basis of the employee's sex. ${ }^{17}$ It can be taken for granted that laws excluding women from particular occupations, with narrow exceptions such as jobs involving military combat, are unconstitutional, and almost all such laws have in fact been repealed. On the other hand, in the Feeney decision the Supreme Court rejected a complaint by women that a state's policy of giving veterans a preference in public employment denied women equal protection because only a minuscule number of women are veterans. ${ }^{18}$

This hasty and oversimplified summary of a complicated legal pattern will make specialists in employment discrimination law wince, but it is sufficient for my economic analysis. Later, however, I shall have to consider a few of the details of the evidentiary and remedial scheme created by Title VII.

\section{Some Economics of Sex Discrimination}

Before the economic effects of sex discrimination law can be evaluated, one must get a grip on the economics of sex discrimination. This section lists the basic assumptions of the analysis, then examines the causes of sex discrimination, and finally makes a stab at estimating what our labor markets would be like today without any sex discrimination laws.

13 See Meritor Savings Bank v Vinson, 477 US 57 (1986).

14 See, for example, AFSCME v Washington, 770 F2d 1401 (9th Cir 1985); American Nurses Ass'n v Illinois, 783 F2d 716 (7th Cir 1986).

1s See, for example, Iowa Code § 602.1401 (1987); and Minn Stat § 471.991-.999 (1984).

${ }^{16}$ See California Federal Savings \& Loan Ass'n v Guerra, 479 US 272 (1987).

${ }_{17}$ See, for example, Los Angeles Dept. of Water and Power $v$ Manhart, 435 US 702 (1978).

18 See Personnel Administrator v Feeney, 442 US 256 (1979). 


\section{A. Assumptions}

I assume that all people-men and women alike-are rational in the usual economic sense. That is, they consistently act to maximize the excess of their private benefits over their private costs. It is consistent with this model, as we shall see, that some-or, for that matter, many or even most-men are misogynistic, exploitative, or ill-informed. I further assume that even if there is no discrimination against women, women will, on average, invest less than men in human capital, both general and job-specific. The qualification that it is only on average that women will invest less is important. The characteristics that are related to productive employment are unevenly distributed within each sex, so that even if the means of the distributions differ, the distributions themselves overlap, with the result that many women invest more in their human capital than many men invest in their own human capital. Nevertheless, the average woman expects to take more time out of the work force than the average man to raise children, ${ }^{19}$ which makes the expected lifetime earnings of the average woman, and hence return to human capital, lower than those of the average man. The average woman will therefore invest less in her human capital, causing her wage to be lower than the average man's, since a part of every wage is repayment of the worker's investment in human capital.

It is possible that the greater propensity of women than men to take time out of the labor force is itself a product of sex discrimination, but I am skeptical of that proposition-I think child-rearing is an area where nature dominates culture-and I do not accept it for purposes of my analysis. However, I will not try to defend this assumption. It is also possible that the propensity will in time disappear, but again I am skeptical, and for the same reason. Even if it does eventually disappear, there can be little doubt that women's current wages are depressed because today's working women did not invest heavily in their human capital when they

10 It is illustrative that in 1984, women who interrupted their work for more than six months gave "family reasons" as the cause of interruption in 40.7 percent of the cases; men mentioned family reasons in only 0.3 percent of the cases. Sara E. Rix, ed, The American Woman 1988-89: A Status Report 379 table 16 (Norton, 1988). In 1986, of all women with children up to the age of six, only a third were employed full time. Id at $375 \mathrm{fig} 11$. The Bureau of Labor Statistics estimated that in $\mathbf{1 9 8 5}$ white males had a "worklife expectancy" at birth of 39.8 years, compared to 29.7 years for white females. U.S. Department of Commerce, Bureau of the Census, Statistical Abstract of the United States 364 table 606 (GPO, 108th ed 1988). In 1987, of married persons aged 20-24, 95.7 percent of the men were working outside the home but only 67.4 percent of the women. Id at 373 table 622 . 
were young. Table 7-3 in the 1987 Economic Report of the President $^{20}$ shows, for example, that while in 1968 only 27.5 percent of young white women expected to be working when they were 35 years old, in 1985 more than 70 percent of these women were working. The table also shows that, by 1979 , young women had changed their expectations: almost exactly the same percentage of young women expected to be working at age 35 as were in fact working at that age in 1985. Since women now have more realistic expectations concerning their labor force participation, we can expect them to invest more heavily in their human capital and therefore earn higher wages in the future. Thus, although the fact that the average woman earns substantially less than the average man is often taken to be prima facie evidence of sex discrimination, it is not, and in any case the differential is likely to decline for reasons unrelated to sex discrimination law.

Finally, I assume that men's and women's utility functions are interdependent, and specifically that women derive a benefit from an increase in the income of a husband or other male relative (son, father, brother, etc.), even if no part of the increased income is consumed by the woman. This qualification is necessary because of the importance of joint consumption in the household. Normally if one spouse's income rises, the other spouse will benefit because so much of the consumption in a household is joint. We thus have separate interdependencies: the "pure" interdependency that results from altruism (the satisfaction that most people experience from an increase in the happiness of a close relative), and the interdependency resulting from joint consumption within the household. For simplicity's sake I shall confine my attention to the interdependencies between wife and husband and ignore other relatives.

It is important to note that the interdependencies between spouses often persist after divorce or the death of a spouse. If a widow's or divorcée's standard of living is a function of her husband's income, increases in that income will increase the wife's welfare. This increase will persist even after a woman is widowed, since her standard of living remains tied to her husband's former income; similarly, a divorced woman's standard of living often remains tied to her former husband's current income. Thus the large percentage of women who are unmarried exaggerates the economic independence of women from men. The vast majority of women marry at some time during their lives, and this is all that is neces-

20 Council of Economic Advisors, Economic Report of the President 215 table 7-3 (GPO, 1987). 
sary to establish a pervasive economic interdependence between the sexes. ${ }^{21}$

The relationship between majority and minority groups is not characterized by interdependence of either the joint-consumption or altruistic varieties, if only because racial intermarriage remains rare. ${ }^{22}$ Interdependence gives the economics of sex discrimination a distinctive cast. To take the extreme case, suppose that all workers were married and that all consumption within the household were joint. Then discrimination against women in the labor force would be compensated for completely in the home, for while wives' wages would be lower than in a nondiscriminatory regime, wives would benefit dollar for dollar from the correspondingly higher wages of their husbands. Of course these assumptions are too strong, and they ignore the fact a woman's earning power may affect her influence over household expenditure decisions, ${ }^{23}$ but they point to an important difference between sex discrimination and the other forms of discrimination with which sex discrimination is often, but perhaps facilely, linked.

\section{B. The Meaning and the Causes of Sex Discrimination}

To avoid building a normative assessment into the word "discrimination," I shall follow the lead of Title VII and define sex discrimination as treating a woman differently from a man because she is a woman, without worrying at the definitional stage about whether the discrimination is invidious on the one hand, or justified or even beneficent on the other. ${ }^{24}$ This definition is more prob-

${ }^{21}$ In 1986, of all white women 15 years and older, 20.9 percent had never been married, 56.4 percent were married and living with their husband, 2.7 percent were married but not living with their husband, 11.8 percent were widowed, and 8.2 percent were divorced. Rix, The American Woman at 354-55 fig 2 (cited in note 19). For black women, the figures are 36.4 percent, 32.4 percent, 8.9 percent, 11.6 percent, and 10.8 percent, respectively. Id. In 1986, among all women 55-64 years old, only 3.9 percent had never been married. Statistical Abstract of the United States at 40 table 49 (cited in note 19). Of course, this figure may decline since fewer women are marrying nowadays. On the changing demographics of American women, see Heidi I. Hartmann, Changes in Women's Economic and Family Roles in Post-World War II United States, in Lourdes Beneria and Catharine R. Stimpson, eds, Women, Households, and the Economy 33 (Rutgers, 1987).

${ }_{22}$ In 1986, out of $51,704,000$ married couples in the U.S., only 181,000 (0.35 percent) consisted of a white and a black. Statistical Abstract of the United States at 40 table 50 (cited in note 19).

2s This depends in part, however, on the structure of family and divorce law, which determines the wife's entitlements in her husband's income.

24 Although there is discrimination against men, I shall ignore it. A more important phenomenon that I do discuss is policy that is designed to combat discrimination against women and has the incidental effect of harming men. 
lematic than it may appear to be, because it leaves unresolved the question whether it is discriminatory (in a sense pertinent to public policy) to treat a woman differently because of a characteristic that no men but only some women have, such as the capacity to bear children. The Supreme Court in Gilbert held that such differentiation was not discriminatory, ${ }^{25}$ but the Court was overruled by Congress. I shall follow Congress's approach and assume that discrimination based on pregnancy is a form of sex discrimination-which is not to say, of course, that it necessarily is inefficient.

When discrimination is defined as broadly as I am defining it, the causes are multifarious. Here are the main ones, in (roughly) descending order of invidiousness. The discussion is confined to employment discrimination, the focus of this paper.

Misogyny. By this I mean an elemental distaste on the part of men for associating with women at work, not founded on any notions of productivity or efficiency. The misogynist, as I am using the word, is not someone misinformed about either the average or individual quality of female employees-he just doesn't like them in the workplace, maybe because he has traditional views of "the woman's place." Misogyny may appear to be a taste like any other, and therefore ethically neutral from an economic standpoint-a given. But this is not so clear. Insofar as it is expressed in hostile behavior, it may be more akin to a taste for assault than to a taste for chocolate ice cream. Perhaps misogyny is in between a harmless taste and an actual externality like rape or theft. But the precise status in economics of misogyny is not important to my analysis. To further complicate the picture I note that a disinclination to associate with women in the workplace need not reflect a dislike of women and could in fact reflect something nearly opposite to dislike-a desire, not necessarily insincere, to protect women from the hardships of the workplace.

Physical or Psychological Aggression. A straightforward case of exploitation, more clearly akin to theft or rape than to misogynistic refusal to accept women workers, is sexual harassment-conduct designed to elicit sexual favors from women against their will. This phenomenon is related to the "conduit" type of discrimination discussed below, because ordinarily it is not the employer himself (more often, itself) who harasses women, but male employees. The employer merely doesn't want to go to the 
expense of preventing harassment by its employees. More precisely, the required expense would exceed the potential benefit to the employer from not having to compensate female employees for the disutility of being sexually harassed.

Ignorance About the Average Working Woman. A man who is not a misogynist may nevertheless labor under serious misconceptions concerning the abilities of working women. This is especially likely if there are few women in the workplaces with which the man is familiar. This ignorance may be rational, but that is not to say that it is admirable. Indeed, it may be rational for the entire market to be misinformed, because of the well-known externality problems with information. Whom would it pay to develop information about the working qualities of women in general? How would the social benefits of such information be translated into private benefits for the producer of the information? The pioneer in hiring women in a particular segment of the work force may simply be paving the way for his competitors to learn from his mistakes. Notice that in an era of minimum wage (and equal pay) laws, a woman cannot compensate her employer for taking a chance with an unknown quantity by accepting a lower wage. However, the minimum wage is not an important factor in professional and other well-paid employment or in periods such as the present when the minimum wage is far below the average wage.

Monopsony. Married women have high relocation costs when the husband earns more than the wife, as is usually the case. In areas where competition for labor among local employers is weak, these employers may be able to set a monopsonistic wage for female employees, so long as such women represent a large fraction of the female labor force or the employer is able to discriminate among women, paying less to those he believes would have difficulty relocating. Monopsony wage-setting is exploitation of female labor in a straightforward economic sense, although it is less invidious than certain other forms of discrimination because it does not rest on any premise that women are inferior workers to men.

Conduit of Discrimination. In many cases of discrimination the discriminator is merely reflecting the tastes of customers, employees, government agencies, or others with whom the discriminator has a commercial or regulatory relationship. If male employees don't like working with women, or if customers don't like female workers, the employer will perceive these aversions as additional costs of hiring women and will hire fewer of them, or will pay the women a lower wage to compensate the employer for their greater cost. 
Statistical Discrimination. Even if employers and their male employees and customers have no discriminatory feelings and are perfectly well informed concerning the average characteristics of women in the various types of job, it may be rational for employers to discriminate against women because of the information costs of distinguishing a particular female employee from the average female employee. For example, the average woman may be physically or emotionally less suited for combat than the average man, even though the two distributions overlap. If it is too costly for the Department of Defense to identify women who are as well suited for combat as the minimally qualified male recruit, the Department may rationally, noninvidiously, decide to exclude all women from combat jobs.

Differentiation Infinitely Costly. Discussions of statistical discrimination normally assume that, while it would not be efficient to ascertain individual qualifications, it would be possible to do so-that is, the cost would not be infinite. But in the case of women, the cost sometimes would be infinite, because the uncertainty is inherent and ineradicable. For example, when an employer hires two 21-year-old workers, one male and one female, he knows that the former, being male, has a shorter life expectancy than the latter, but he doesn't know and ordinarily couldn't discover whether this female will outlive this male. Similarly, he knows that the man is likely to take less sick leave than the woman, ${ }^{26}$ but this is just betting on the averages-he doesn't know whether these two workers will track the average experience of male and female workers. If differentiations are to be made, they must be made on a statistical basis.

Three things should be noted about my list of the causes of sex discrimination. The first is that it describes a world without sex discrimination laws; for example, we shall see that the problem of "rational ignorance" would be less serious if there were no Equal Pay Act. The second thing to note is the importance of information costs. Half the causes I have identified are based on such costs: ignorance of the average qualities of women workers, statistical discrimination, and inherent uncertainty. Third, only half the causes reflect market failure in a clear economic sense: monopsonistic exploitation of higher relocation costs, aggression against women, and ignorance of the average qualities of women due to

${ }^{26}$ In 1985, the average female worker lost six days of work because of illness or injury; the average male, 4.8 days. Statistical Abstract of the United States at 105 table 166 (cited in note 19 ). 
information externalities. The other forms of discrimination are, or at least may be, efficient-which does not necessarily make them good from an ethical standpoint. Misogyny, for example, is a morally unattractive trait, but from an economic standpoint it may be no different in character from having an aversion to cabbage or rutabaga, though then again it may.

Of the three causes of sex discrimination in employment that clearly reflect a market failure, one has little or no contemporary importance: ignorance of the average qualities of women workers. So many women are employed in so many and diverse fields that few employers can be ignorant any longer concerning women's abilities as workers. The time when the law might have done something to eliminate this information externality is long gone. Another cause, high relocation costs conferring monopsony power on employers, has probably never been very important; I do not recall having seen it mentioned in the literature on female employment. The third cause, sexual harassment in the workplace, probably is largely self-correcting. As more and more women are employed, the employer's self-interest in curbing intrigue and harassment, which lower productivity, grows apace.

I conclude that there is no strong theoretical reason to believe that sex discrimination, even if not prohibited by law, would be a substantial source of inefficiency in American labor markets today. If $I$ am correct, then the costs of administering that law will be largely a deadweight loss, from an economic standpoint. That does not make the law immoral or unjust, but any deadweight losses from law enforcement must be considered in deciding whether a particular law or set of laws furthers the public interest.

\section{Discrimination Trends, Ex Law}

How much sex discrimination of any sort could we expect today if there were no sex discrimination laws or other pertinent governmental interventions (for example, subsidies for day care)? Some, surely; for we have just seen that some, perhaps most, forms of differential treatment are efficient. But sex discrimination would probably be declining, perhaps steeply, even in the absence of any laws against sex discrimination.

The engine of decline is the increasing participation of women in the work force. No one thinks that discrimination would keep all women from working, any more than racial discrimination keeps blacks from working. The main effect would be to depress the wages women were paid, lower their fringe benefits, and alter the distribution of women among jobs. There would, however, be some 
effect on the total number of women employed-more so, indeed, than on the number (as distinct from wages and working conditions) of blacks employed. This is because the elasticity of the supply of labor is higher for women than for men, a phenomenon especially pronounced when a higher percentage of women were married and raising children than is the case today. A married woman, especially with children at home, is in an economic sense "employed" in the home, and her household income will be less if she works in the market. Therefore a small reduction in market wages may keep many women out of the labor market, and conversely a small increase in those wages may draw many women into the labor market.

Women began working in large numbers long before sex discrimination in the workplace was widely criticized, let alone prohibited, and certainly long before sex discrimination ceased to be rampant (some believe it is still rampant). The percentage of the labor force that is female has grown steadily since $1947,{ }^{27}$ and the primary causes of this growth could not be anti-discrimination laws. The other causes of the increased female participation in the work force are by now well-known. With the decline in infant and child mortality, with improved techniques of contraception, and with the advent of inexpensive household labor-saving devices, women spent less time pregnant and raising children and doing household chores, so their opportunity costs of working in the market fell. At the same time, work was becoming less strenuous, in part because the entrance of large numbers of women into the work force increased the demand for services, hence for service workers, who do lighter work than industrial workers. So the demand for female workers rose, and hence their wages rose. As their wages rose, the opportunity costs of pregnancy and child raising rose too, reinforcing the trend toward fewer pregnancies. This in turn reduced the benefits of marriage to both men and women. The improvement in female job opportunities also reduced women's dependence on men. For both reasons, marriage rates fell and divorce rates soared: the former trend increased women's incentive to invest in their human capital, because they were working more; the latter increased the pressure on women to work, both as insurance against divorce and to maintain their standard of living after divorce. ${ }^{28}$

${ }^{27}$ See Fuchs, Women's Quest for Economic Equality at 12 fig 2.1 (cited in note 2); Rix, The American Woman at 366 table 9 (cited in note 19).

${ }^{28}$ See references in note 2; see also Fredricka Pickford Santos, The Economics of Mari- 
Assuming that the increased female participation in the labor force is largely independent of the laws forbidding sex discrimination, one may ask what effect the increase is likely to have had on the incidence of sex discrimination (still ex law). It should reduce that incidence. First, as more women enter the work force, misconceptions concerning the average qualities of female workers should become less common. Of course, if the misconception consisted of exaggerated those qualities, women would be worse off by the elimination of the misconception. But the likelier misconception about a class of people not commonly encountered in the work force is that they are not as good as the existing workers, and this misconception would tend to dissipate with the entry of large numbers of that class into all kinds of jobs.

Second, as more wives and daughters enter the work force, we can expect misogyny to decline. Men who love their wives and daughters and empathize with their wives' and daughters' efforts to find work and to cope with misogynistic coworkers or supervisors are less likely to be misogynists in the workplace than if they lacked this family experience. Third, as more women enter the work force misogynistic employers are placed at a competitive disadvantage: their labor costs are higher than nonmisogynists' because their employment decisions are constrained by misogyny. Fourth, with more and more women workers, sexual harassment becomes more costly. Apart from the impact on productivity noted earlier, a larger fraction of the work force is offended by it, so the total compensating differential that the employer must pay its female employees rises.

As discrimination falls, we can also expect the wage gap between men and women to fall. Another factor working in this direction is the growing value of women's work relative to men's as physical strength becomes a less important labor asset. The declining wage gap among current workers may be masked, however, by an influx of new women workers, since less experienced workers are paid less than more experienced ones. ${ }^{20}$ Thus a reduction in discrimination can actually lower average female wages, rather than, as one would expect, raise them.

Because economic analysis predicts that sex discrimination

tal Status, in Cynthia B. Lloyd, ed, Sex, Discrimination, and the Division of Labor 244 (Columbia, 1975).

20 See James P. Smith and Michael Ward, Women in the Labor Force and in the Family, $3 \mathrm{~J}$ Econ Perspectives 9 (1989); June O'Neill, The Trend in the Male-Female Wage Gap in the United States, $3 \mathrm{~J}$ Labor Econ S91 (1985). 
would have declined and the wage gap between men and women narrowed since 1963, when the first federal sex discrimination law-the Equal Pay Act-was passed, these trends cannot automatically be attributed, even in part, to law. Law may have had little or even nothing to do with improvements in women's status in the labor force. This suggestion may seem paradoxical: if the law penalizes certain conduct, the economist's "Law of Demand" implies that the conduct will become less frequent. This assumes, however, that the law is effective, and it may not be, for reasons to be examined in the next section.

The effect of sex discrimination laws on discrimination is ultimately an empirical question-and a difficult one. As argued above, discrimination would have declined without those laws-indeed was declining, before those laws were enacted-and it is difficult to isolate the effect of one variable from the others pushing in this direction. Victor Fuchs remarks:

It is easy enough to find particular instances where these laws opened up jobs that were previously closed to women or resulted in a realignment of women's pay scales, but it is difficult to see any major effects on broad trends in women's wages or employment. The Equal Pay laws were passed in 1963 and 1964 [Fuchs is referring to the Equal Pay Act of 1963 and to Title VII], but fifteen years later the women/men wage ratio was unchanged at about 60 percent. It was only in the 1980s that the ratio started to climb, but these were the 'Reagan years'-a period not noted for vigorous enforcement of antidiscrimination and affirmative action legislation. With regard to women's employment, the rate of increase prior to the legislation was as rapid as after the laws were passed. ${ }^{30}$

This is painting with a pretty broad brush; other scholars have found that sex discrimination law has helped to break down barriers to the employment of women in traditionally male occupations. ${ }^{31}$ Here is Morley Gunderson's cautious summary: "Clearly, the evidence does not unambiguously indicate that the EEO [Equal Employment Opportunity] initiatives of Title VII were a resounding success, although there is some evidence of a positive

30 Fuchs, Women's Quest for Economic Equality at 27 (cited in note 2).

${ }^{31}$ See, for example, Beller, $17 \mathrm{~J}$ Human Resources at 388-90 (cited in note 4); Leonard, $2 \mathrm{~J}$ Labor Econ at 459 (cited in note 4); James V. Koch and John F. Chizmar, Jr., Sex Discrimination and Affirmative Action in Faculty Salaries, 14 Econ Inquiry 16 (1976). There is, however, contrary evidence besides Fuchs's. See, for example, Smith and Ward, $3 \mathrm{~J}$ Econ Perspectives at 15-16 (cited in note 29). 
effect on the earnings and occupational position of women. There is also some evidence that the legislation is more effective when it is strictly enforced and when the economy is expanding." ${ }^{32}$ There is no evidence of large effects ${ }^{33}$ - and we shall see that sex discrimination law may not have improved the net welfare of women even if it has somewhat reduced the amount of sex discrimination.

Moreover, the costs of administering the sex discrimination laws must be factored into any attempt at an overall evaluation of those laws. No laws are costless to enforce, not even ineffectual ones. The burdens that sex discrimination laws place on the courts are substantial, and are growing even as discrimination is declining. John Donohue and Peter Siegelman have shown in a recent paper that declining discrimination may be associated with a rise rather than (as one might expect) a fall in the number of cases brought, because as more women are employed in better-paying jobs the gains from suit rise, and because women working side by side with men have a benchmark for proving unequal treatment. ${ }^{34}$

\section{An Economic Examination of Specific Laws and DOCTRINES}

Having sketched the basic sex discrimination laws and the basic economics of sex discrimination, I am prepared to analyze those laws from an economic standpoint. The highly tentative character of the analysis should be self-evident.

\section{A. Equal Pay Act}

At first glance this is the least problematic of the sex discrimination laws. If work is really equal (and the Act has, as I have

${ }^{32}$ Gunderson, $27 \mathrm{~J}$ Econ Lit at 61 (cited in note 2) (emphasis in original). For a similar appraisal of Executive Order 11246, see id at 63-64. Notice in regard to the last sentence in the quoted passage that the more the government impedes the efficiency of labor markets the less likely the economy is to be expanding.

ss See also Cynthia B. Lloyd and Beth T. Niemi, The Economics of Sex Differentials 304-07 (Columbia, 1979). But there is an exception: Leonard, $2 \mathrm{~J}$ Labor Econ at 459 (cited in note 4), found that the executive order had increased the demand for white women by employers subject to the order by 3.5 percent relative to the demand for white men, but the demand for black women by 11 percent relative to the demand for white women. The reason may be that hiring a black woman enables the employer to make progress toward two affirmative action goals at once.

s4 See John J. Donohue and Peter Siegelman, The Changing Nature of Employment Discrimination Litigation (Am Bar Found, unpublished April 1989). Their discussion covers racial as well as sexual discrimination, and reaches the same conclusion: as blacks move into higher-paid positions and work in integrated jobs, the net expected gains from filing employment discrimination suits rise. 
noted, been narrowly construed in this regard), then it would seem that unequal pay could not be efficient-it must reflect price discrimination. But it is more correct to say that it may reflect price discrimination. If the employer is able to pay its female employees a monopsonistic wage because of their high relocation costs, then it is discriminating in the economic (price discrimination) sense. Another possibility, however, is that while the work is nominally equal, the men do it better-are more productive-on average than the women, yet the employer is unable to prove this "factor other than sex" (which, as mentioned above, is a defense under the Act).

A third possibility is that the employer pays its female employees less because the employer's male owners, male managers, or male employees have an aversion to women in the workplace. Then the Act will operate as a tax on misogyny. Such a tax is not objectionable in itself, but we must consider the employer's likely reaction. He (the male pronoun being particularly appropriate in this context) will try to reduce the tax, by hiring fewer female employees, creating working conditions that are not attractive to them, or-the simplest strategy-placing women in jobs where they are doing work that is not equal to men's work. These would not be feasible strategies if Title VII were totally effective, for virtually all the measures that an employer might take to avoid the mandate of the Equal Pay Act would be a form of sex discrimination forbidden in principle by Title VII. Even substituting computers for secretaries might violate Title VII if the employer's motive were to reduce the number of female employees. But if we assume, realistically, that the Equal Pay Act is easier to enforce than Title VII, then the Act will result in fewer women being employed even if the average wage of those women who are employed is higher. ${ }^{35}$ And the average wage may not be higher if the employer responds to the Act by shifting women to jobs where their

35 For some evidence that the Act (and its foreign counterparts) has had this effect, see Isabel V. Sawhill, The Economics of Discrimination Against Women: Some New Findings, $8 \mathrm{~J}$ Human Resources 383, 393-94 (1973); Shaffer, 26 Labor L J at $294 \mathrm{n} 10$ (cited in note 4); Jacob Mincer, Intercountry Comparisons of Labor Force Trends and of Related Developments: An Overview, $3 \mathrm{~J}$ Labor Econ S1, S30 (1985); Maureen Pike, The Employment Response to Equal Pay Legislation, 37 Oxford Econ Papers 304, 316 (1985). It has even been argued that the covert purpose of the Equal Pay Act was to help men compete with lowerpaid women. See Nancy S. Barrett, Women in the Job Market: Occupations, Earnings, and Career Opportunities, in Ralph E. Smith, ed, The Subtle Revolution 31, 55 (Urban Institute, 1979), citing Jo Freeman, The Legal Basis of the Sexual Caste System, 5 Valp U L Rev 213, 226-27 (1971). A comparable effect on blacks was found in a study of state fairemployment laws. See William M. Landes, The Economics of Fair Employment Laws, $76 \mathrm{~J}$ Pol Econ 507, 544-45 (1968). 
work is not equal to men's. In addition, the Act will prevent women from attempting to overcome any information barriers to hiring them that may exist by offering to work for a lower wage than men.

Even if the employer does not try to avoid or evade the Equal Pay Act there may be a disemployment effect. The Act operates as a payroll tax, and the tax is higher the more workers employed. The employer may raise price in an effort to offset the tax, but unless he faces a totally inelastic demand curve-which no seller does-the increase in his price will reduce the demand for his goods, leading him to curtail his output and hence inputs, including labor inputs. He will employ fewer women as well as fewer men.

Another point is that the employer may avoid the Act unconsciously. He may simply observe that a department which happens to employ many women now has higher costs and lower profits than it used to, and may decide to reduce the size of the department without knowing or caring why its profit margin has fallen. All he needs to know is that his capital will command a higher return in an alternative use.

To the extent that unequal pay reflects differences in productivity that the equal work standard of the Act is insufficiently sensitive to pick up, the Act's distributive consequences are complicated by the interdependencies between men and women noted earlier in this article. If employers must pay a single wage to workers of different average productivity (i.e., men and women), that wage will be lower than that which the more productive workers would command but for the prohibition of "discrimination." So both men (by hypothesis, the more productive group) and their wives will be worse off. By the same token, the husbands of married women whose pay rises as a result of the Equal Pay Act will be better off. But if women are more altruistic on average than men, ${ }^{36}$ the increase in men's welfare resulting from an increase in their wives' income will be less than the decrease in women's welfare resulting from a decline in their husbands' income, even if the increase and decrease are identical in dollar terms. In addition, since more married men than married women work, the transfer of welfare to married women will be larger. When this consideration is added to the Equal Pay Act's potential disemployment effect on women, it becomes a plausible speculation (again, no stronger con-

\footnotetext{
${ }^{36}$ See generally, Carol Gilligan, In a Different Voice: Psychological Theory and Women's Development (Harvard, 1982).
} 
clusion is possible) that the Act makes women as a group worse off.

\section{B. Title VII}

Two different types of Title VII sex discrimination cases should be distinguished. In a disparate impact case, the employee challenges a practice (for example, a height requirement, or a prohibition, as part of an "anti-nepotism" rule, on hiring employees' spouses) that has a disproportionate exclusionary effect on women, though it was not intended to exclude them. Traditionally, such a practice was unlawful unless the employer could show that it was a business necessity; in practice such a showing was difficult to make. Disparate impact litigation has been important in eliminating personnel practices that tended to exclude blacks (i.e., requiring a high-school diploma), but has not been very important in the area of sex discrimination. Most practices challenged under disparate impact theories involve tests and credentials, and these are rarely sex-biased. Recently, the Supreme Court watered down the "business justification" defense and shifted the burden of proof to the plaintiff, so we can expect disparate impact cases to decline. ${ }^{37}$

The other, and more common, type of sex discrimination case is the disparate treatment case. This requires proof that the employer intentionally treated the female employee (or applicant) less favorably than it would have treated a similarly situated male employee. The practical difficulties in such litigation are great. First, it is difficult to prove a complex counterfactual (for example, what would have happened if the employee had been male rather than female). Second, it often does not pay the plaintiff to invest in the necessary proof-which involves looking at similarly situated males to show that the plaintiff's inadequacies were not responsible for her being fired or otherwise mistreated..$^{38}$ The stakes are small. They consist of backpay minus whatever the plaintiff has earned in a substitute job (for the employee has a duty to mitigate her damages) plus reinstatement. But reinstatement will rarely be sought, since usually the plaintiff will have gotten another job while the litigation was pending and will be reluctant to go back to work for an employer who mistreated her and whom she sued. Finally, bringing an employment suit impairs the plaintiff's earning capac-

37 Wards Cove Packing Co., Inc. v Atonio, 109 S Ct 2115 (1989).

${ }^{38}$ Rarely will an employer fire, or otherwise treat badly, a perfect worker, of whatever race or sex. Discrimination is more apt to be directed against workers who are not, or not much, better than average, and whose complaint is that the employer took a dimmer view of their failings than he would have of a white male's failings. 
ity: employers are reluctant to hire people who sue employers ${ }^{39}$

Although the plaintiff's costs in bringing successful sex discrimination litigation under Title VII may well outweigh her gains, there is an important qualification. If class action treatment is possible, as where a large employer is alleged to be discriminating against all or most of its female employees, then plaintiffs will find safety in numbers and it will be feasible for them to develop statistical evidence of discrimination. Yet such evidence often is inconclusive. It usually comes down to an unexplained difference in the wages or number of men and women employed, and it is always possible for the employer to argue that the statistical methodology is insufficiently sensitive to identify all noninvidious explanatory variables.

To the extent that disparate treatment suits do succeed, it is uncertain whether they increase the net welfare of women. Since some forms of unlawful sex discrimination are efficient, Title VII litigation will reduce the efficiency with which employers use labor, and this will result in lower average wages and higher product prices. The direct costs of Title VII litigation-lawyers' fees, executive time, and so forth-will work in the same direction. Full-time housewives will bear a disproportionate share of these costs, since their husbands' wages will fall and the prices they and their husbands pay for goods and services will rise. ${ }^{40}$ Conversely, single working women will tend to benefit, except to the extent that employers are reluctant to hire women in the first place out of fear that Title VII will restrict their ability to fire an unsatisfactory female employee without inviting a lawsuit.

\section{Comparable Worth}

Failure to achieve "comparable worth" has sometimes been challenged under the disparate impact theory of Title VII, but without success. Jobs traditionally dominated by women (the stereotypical examples are nursing and secretarial work) are on average less well paid than jobs traditionally dominated by men, such as truck driving. Proponents of "comparable worth" argue that the disparity reflects sex discrimination and can be eliminated by re-

${ }^{38}$ On the reluctance of women for this reason to bring sex-discrimination suits see Kristin Bumiller, The Civil Rights Society: The Social Construction of Victims 26 (Johns Hopkins, 1988).

10 There are fewer full-time housewives today than there used to be, but there are still plenty. In 1985, 23.5 percent of all families had a full-time housewife. Rix, The American Woman at 374 table 14 (cited in note 19 ). 
quiring employers to pay wages "objectively" commensurate with the skill, responsibility, and other attributes of each job. The short economic answer is that a competitive labor market will achieve comparable worth; for that is the equilibrium condition of such a market. If a particular job classification happens to be overpaid relative to skill, responsibility, and other considerations that determine the value and cost of a worker's time, workers will flow into the classification, reducing the wage until the excess demand is eliminated. And if the job classification happens to be underpaid, workers will leave for better jobs, causing the wage to rise.

There are, however, three important qualifications to this economic answer; the first two are closely related. First, the equilibrium that results will reflect any systematic wage differences that are due to efficient sex discrimination; and some, maybe most, discrimination is efficient. Second, to the extent that employers "steer" women into traditional women's jobs and men into traditional men's jobs, and this discrimination is not detected and prevented through enforcement of Title VII, competition will not eliminate discrimination based on sex. Finally, public employer labor markets may not be competitive; hiring and firing may be determined by political rather than economic considerations. Thus, requiring public employers to achieve comparable worth is less likely to produce market distortions than requiring private employers to do so. ${ }^{41}$

A deeper objection to making comparable worth mandatory in private markets is that comparable worth neglects important factors that bear on the determination of a competitive wage, such as investment in human capital. Women who because of voluntarily assumed family responsibilities expect to participate only intermittently in the labor market will be attracted to jobs that do not involve as great an investment in human capital, and such jobs will not (and from an economic standpoint) should not pay as well. Also, comparable worth does not take into account the desirability of allowing wages to fluctuate in order to correct temporary imbalances between supply and demand, when a particular labor market is not in equilibrium. Finally, if wages are set on the basis of what is deemed to be comparable worth and, as is likely, the resulting

41 For evidence in support of these three points see Richard F. Kamalich and Solomon W. Polacheck, Discrimination: Fact or Fiction? An Examination Using an Alternative Approach, $49 \mathrm{~S}$ Econ J 450 (1982); Bielby and Baron, 76 Am Econ Rev Papers \& Proc 43 (cited in note 3); and Elaine Sorensen, Implementing Comparable Worth: A Survey of Recent Job Evaluation Studies, 76 Am Econ Rev Papers \& Proc 364 (May 1986), respectively. 
pattern is not the equilibrium pattern for the labor market in question, entry or exit will occur until the old "discriminatory" pattern is restored. In other words, if women (for whatever reason) prefer "traditionally female" jobs, once the wages in those jobs rise women will enter these occupations in great numbers, driving the wage back down. Hence a commitment to comparable worth implies not merely one-time, but continuous, intervention in competitive wage-setting.

Even if comparable worth were fully achieved, women as a whole might not be better off. Women in the traditional women's jobs would have higher wages, but fewer of them would be employed, because employers would have an increased incentive to substitute capital for these jobs and, to the extent substitution was infeasible, to reduce the scale of the activity in which these women were employed. In general, then, comparable worth can be expected to reduce the employment of women ${ }^{42}$ as well as to transfer wealth from childless women to mothers, since the latter are more likely to be attracted to traditional women's jobs, those being the jobs for women who want to balance family and career. In addition, the social costs resulting from so massive a public interference with labor markets would be great and would be borne in significant part by women, as we have seen.

\section{Sexual Harassment}

When efforts were first made to attack sexual harassment under Title VII they seemed an exotic extension of the statute, in part because of the strange implication that a bisexual harasser couldn't be liable under the Act, since his conduct was sex neutral. However, the case for prohibiting sexual harassment may actually be stronger from an economic standpoint than the case for prohibiting conventional sex discrimination. Sexual harassment, properly defined to exclude mere flirtations and solicitations, is a coercive practice related to such plainly inefficient practices as rape and extortion. ${ }^{43}$ Sexual harassment is unlikely, save for the costs of prevention, to be in the employer's interest. While, in principle, grant-

42 For evidence see June O'Neill, Michael Brien, and James Cunningham, Effects of Comparable Worth Policy: Evidence From Washington State, 79 Am Econ Rev Papers \& Proc 305, 308 (May 1989); Mincer, $3 \mathrm{~J}$ Labor Econ at S29-S30 (cited in note 35); see also Johnson and Solon, $20 \mathrm{U}$ Mich J L Ref at 202-03 (cited in note 4); Mark R. Killingsworth, The Economics of Comparable Worth: Analytical, Empirical, and Policy Questions, in Heidi I. Hartmann, ed, Comparable Worth: New Directions for Research 86 (National Academy, 1985).

${ }^{4}$ See Posner, Economic Analysis of Law at 201 (cited in note 1). 
ing a "license" to male supervisory employees to harass female employees would enable the employer to pay a lower wage to those male employees, the reduced cost of hiring supervisors is unlikely to offset: (1) the higher wage the employer will have to pay its female employees to compensate them for being exposed to sexual harassment; (2) time lost by employees in harassing or warding off harassment; (3) distortion in promotions; and (4) adverse selection of employees (the employer would be a magnet for male employees wanting to harass females and for female employees desiring to use their wiles to gain advancement). The problem is that, like other antisocial behavior in the workplace (embezzlement, for example), the costs of prevention are high; and this is an argument for public enforcement-depending of course on its costs.

The novelty in the legal concept of sexual harassment is that the usual defendant in a Title VII sexual harassment case is not the harassing male employee, but the employer. It is as if banks were the defendants in cases involving embezzlement by bank employees. The proper analogy, however, is to the tort doctrine of respondeat superior. The most efficient method of discouraging sexual harassment may be by creating incentives for the employer to police the conduct of its supervisory employees, and this is done by making the employer liable. Because "employer" is broadly defined in Title VII, the supervisory employee himself can be and sometimes is made a defendant in a Title VII sexual harassment case; so again the analogy to respondeat superior (which is an additional ground of liability, not a defense for the primary tortfeasor) is a close one.

\section{E. Pregnancy Discrimination Act}

The requirement that the employer not differentiate among its employees on the basis of pregnancy is analytically the same as a requirement that the employer pay the same retirement benefits to male and female employees despite women's superior longevity, or a requirement that the employer grant maternity leave (in other words, agree to reinstate female employees who take time off to have or take care of their babies). In all three cases, the law compels the employer to ignore a real difference in the average cost of male and female employees. The result is inefficient, but a more interesting point is that it may not benefit women as a whole. ${ }^{44}$

14 Moreover, unisex longevity tables penalize women buying life insurance, unisex liability insurance premium-setting penalizes women because they are safer drivers than men, 
The employer is required in effect to pay them greater fringe benefits than men (since health care for pregnancy is a benefit men do not require). The employer cannot recoup by reducing women's wages-that would violate the Equal Pay Act-but he can minimize his costs by employing fewer women (as by automating secretarial work faster and more completely). To the extent that this succeeds, women will be hurt. To the extent it does not succeed, the employer will experience a rise in his average cost of labor, causing him to reduce the average wage he pays.

Women will lose not only directly, but also indirectly, in their role as the wives of men who will now be paid less. The clearest loser will be a married but childless working woman. ${ }^{45}$ Her wage and that of her husband will fall, and she will not recoup the loss in higher fringe benefits, because the additional benefits are of value only to women with children. And even if the aggregate income of the household is higher, women may have less power within the household if their paychecks are smaller. This, however, is pure speculation-it is far from clear that women's consumption within the household depends on the relative size of the woman's paycheck, as distinct from her relative contribution to the full (nonpecuniary as well as pecuniary) income of the household. Housewives will also suffer from the Pregnancy Discrimination Act because their husbands' wages will fall. The point can be generalized: housewives, being economically identified with their husbands, are hurt by efforts to reduce sex discrimination. The clearest beneficiaries of sex-neutral fringe benefits are unmarried working women with many children-a small group.

This analysis, by illustrating the possibility of deep conflicts of interest among women, may help explain why many women are not feminists. Depending on age, marital status, number and age of children, and other factors, women may gain or lose from measures ostensibly designed to eliminate discrimination "against women." Indeed, women are so heterogeneous a group that it is hard to imagine what public policies would benefit them as a group-except

and preventing insurers from differentiating among risk groups on the most efficient basis increases the social costs of insurance. These effects illustrate the tendency of sex discrimination law to bring about offsetting redistributions of wealth. Such redistributions are not costless. The only argument for them is that they will contribute to breaking down stereotypes. This is implausible. It is not a stereotype, but a fact, that women live longer than men, have fewer accidents, incur greater medical expenses, and so forth.

15 There are many women in this category. In 1985, 17.1 percent of all families were childless married couples in which both spouses were working. Rix, The American Woman at 374 table 14 (cited in note 19). 
policies designed to maximize social wealth by maintaining and strengthening free markets.

\section{F. Equal Protection}

The interpretation of the Equal Protection Clause as prohibiting sex discrimination in employment unless the discrimination is justified by an important governmental interest has thus far had little effect. Much of the prohibition overlaps Title VII. Many cases have been brought by men rather than women, although women's groups generally support these cases on the ground that they combat stereotypes harmful to women's aspirations for job equality. ${ }^{46}$ Many cases have the usual ambiguous effects. Consider the requirement that spousal benefits under social security programs be equalized regardless of the sex of the spouse, so that a widower is entitled to the same social security death benefit as a widow. If the total benefits payable under social security are assumed to be fixed, the result of this entitlement will be to benefit the better off at the expense of the worse off, since widowers are on average wealthier than widows. The Feeney decision, ${ }^{47}$ upholding Massachusetts' policy of giving veterans a preference in public employment, illustrates the possibility that the optimal ideology for the women's movement may well be a libertarian one. Veterans' benefits programs, which of course systematically benefit men over women, are redistributive measures that are contrary to the principles of efficiency and limited government.

\section{ConCLUSION}

What has been the net effect of the cascade of laws and lawsuits aimed at eliminating sex discrimination in employment? This is maddeningly difficult to say, but it is possible that women as a whole have not benefited and have in fact suffered. Because of the heterogeneity of women as an economic class and their interdependence with men, laws aimed at combating sex discrimination are more likely to benefit particular groups of women at the expense of other groups rather than women as a whole. And to the extent that the overall effect of the law is to reduce aggregate social welfare because of the allocative and administrative costs of the law,

16 The fact that laws ostensibly discriminating in favor of women may actually harm them suggests that laws ostensibly forbidding discrimination against women may also harm women.

47 Personnel Administrator v Feeney, 442 US 256 (1979). 
women as a group are hurt along with men. Sex discrimination has long been on the decline, for reasons unrelated to law, and this makes it all the more likely that the principal effect of public intervention may have been to make women as a group worse off by reducing the efficiency of the economy. The case for ambitious extensions of sex discrimination law-for example in the direction of comparable worth-is therefore weak.

These suggestions should not be surprising, in light of the extensive, and largely negative, economic literature on regulation. There is a tendency to suppose that laws forbidding discrimination are somehow exempt from the critique of regulation. This position is difficult to sustain.

It is possible that the economic costs of sex discrimination law are offset by gains not measured in an economic analysis-gains in self-esteem, for example. But it is not clear that, if the canvass is broadened in this fashion, the picture brightens. For example, if by reducing the wages of men sex discrimination law propels more wives into the job market, with the result that (since they still bear the principal burden of household production) they work harder, have fewer children, and have less stable marriages, it is not clear that they are better off on balance than they were when their husbands had higher wages and they stayed home. The social, like the economic, consequences of sex discrimination law are murky, and not necessarily positive. In any event it is important to know what the sex discrimination laws cost; the price tag for an increase in women's self-esteem, if known, might be thought too high by society. 
